\title{
GROUNDWATER QUALITY MAPPING OF NANDIARU SUB- BASIN, TAMILNADU, INDIA BY USING GEO SPATIAL TECHNOLOGY
}

\author{
K. Prabhu ${ }^{1,2, *}$ and R. Sivakumar ${ }^{1}$ \\ ${ }^{1}$ Department of Civil Engineering, SRM Institute of Science and Technology, \\ Kattankulathur-603 203, Tamilnadu, India. \\ ${ }^{2}$ Department of Civil Engineering, GRT Institute of Engineering \& Technology, \\ Tiruttani-631 209, Tamilnadu, India. \\ *E-mail : k.prabhumtech@gmail.com
}

\begin{abstract}
The surface and Groundwater are the most important natural resources of human life. Now a day's Groundwater has become an essential resource due to an increase of its need for domestic, agricultural and industrial uses etc., consequently groundwater quality is very important as its quantity. The present study has shown the spatial variability of groundwater quality mapping for NandiAru sub-basin, Tamilnadu, India using geo-spatial technology. The borehole water samples were collected randomly at 50 sampling locations of the entire study area. The most important parameters of water quality such as $\mathrm{pH}$, TDS, EC, $\mathrm{Ca}, \mathrm{Na}, \mathrm{Mg}, \mathrm{Cl}, \mathrm{K}, \mathrm{SO}_{4}, \mathrm{PO}_{4}, \mathrm{NO}_{3}, \mathrm{~F}_{\text {and }} \mathrm{H}_{2} \mathrm{SiO} 4$ has been tested for all the water samples in order to understand the hydro geochemistry of the groundwater. Based on the water quality parameter results were compared with standard parameter values suggested by the Bureau of Indian Standards (IS 10500:2012) for drinking water suitability. The spatial contour map of these groundwater quality parameters was derived in GIS software using an interpolation technique. The overlay analysis was carried out for different spatial contour maps to prepare the groundwater quality map of the study area.
\end{abstract}

Keywords: groundwater, water quality parameters, spatial contour maps, overlay analysis

(C) RASĀYAN. All rights reserved

\section{INTRODUCTION}

Water is flowing in two forms, namely surface water and groundwater. Water flowing on Earth surface is called surface water and circulating below the ground is called groundwater. Groundwater is one of the important water sources that meet domestic, irrigation, and industrial requirements ${ }^{9}$. Since groundwater plays a very important role and the same as the primary source of water for living components. Groundwater is a mixture of various constituents since it flows below ground and during its pathway within the different formation and residences, which makes it for serving various purposes. The pollution with respect to groundwater not only affects the quality but also creating dangerous effects on the human health, social prosperity, and all-round development of our country ${ }^{5}$. Therefore groundwater quality monitoring has become very essential. Geospatial technology is the latest one available to various thematic data can store, analyze and manipulate for the natural resources management ${ }^{6}$. The existing groundwater quality condition monitoring and management of polluted areas are identified using GIS software. The GIS-based groundwater quality mapping and its suitability evaluation for irrigation and domestic purpose ${ }^{4}$. The study area having the issues of environmental pollution due to the dying factories, untreated sewage water released into the river system, dumping of debris (Solid Waste) into water bodies. The present study has made to prepare the various thematic maps of groundwater quality parameters spatial variation for NandiAru sub-basin, Tamilnadu, India using Geospatial Technology.

\section{Study area}

The study area "NandiAru sub-basin" covered in the part of two districts, namely Tiruvallur and Vellore district of Tamilnadu and a small adjacent part in Chittore district of Andhra Pradesh. 
The study area (Fig.-1) sub-basin located between the latitudes $13^{\circ} 03^{\prime} 28^{\prime \prime} \mathrm{N}$ to $13^{\circ} 15^{\prime} 59^{\prime \prime} \mathrm{N}$ and longitudes $79^{\circ} 17^{\prime} 30^{\prime \prime E}$ to $79^{\circ} 43^{\prime} 25^{\prime \prime} E$ covering an area of $710 \mathrm{~km}^{2}$. It falls under the survey of India toposheets No's 57O/8, 11 and 12 of 1:50,000 scale. The basin partially covered five taluks viz Pallipattu, Puttur, Walaja, Tiruttani and Arakkonam. The sub-basin has hot and dry summer during the months of March to August and very cold and misty winter from September to February. The temperature varies from $17^{\circ} \mathrm{C}$ to $45^{\circ} \mathrm{C}$. The tube/bore wells, wells and the tanks are the important irrigation sources in the area. The depth of bore wells varies from $140 \mathrm{ft}$ to $450 \mathrm{ft}$ over all the sub-basin. The study area is primarily composed of numerous crystalline rocks as well as sedimentary rocks of which migmatite gneiss is the predominant rock, amphibolite, charnockite, granite, and pink hornblende biotite gneiss, each one covering small portions of the study area. The regional falling gradient is towards the eastern side and the thickness of study area weathered zone varies from $0.448 \mathrm{~m}$ to $53.5 \mathrm{~m}$.

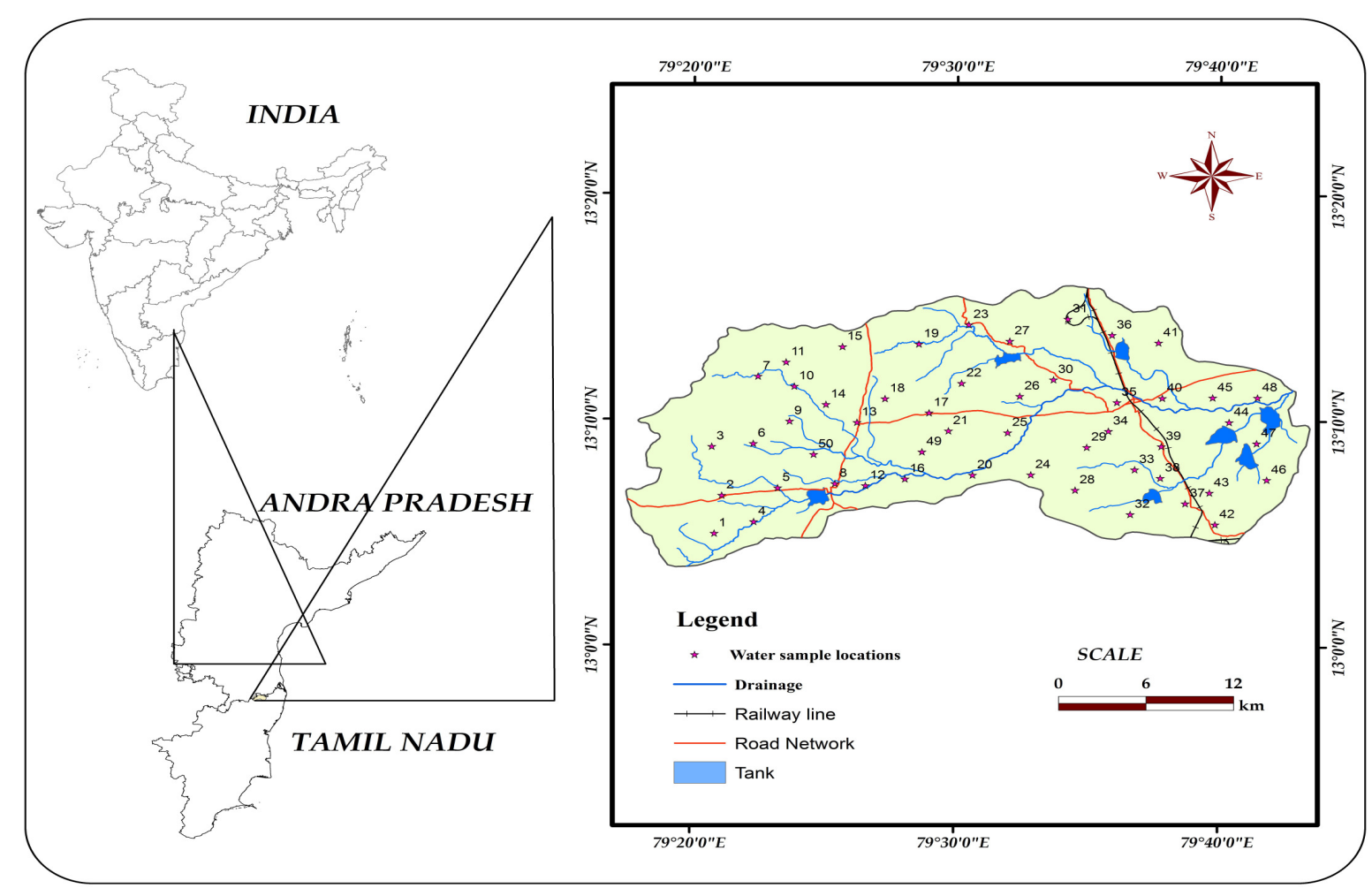

Fig.-1: Location map of the study area

\section{EXPERIMENTAL}

The methodology involves the collection of fifty water samples from the bore wells to cover various rock units of the study area. Further, the collected groundwater samples quality of major cations and anions were analyzed by using standard procedures. Using the electrode specifically in the field for EC, salinity and alkalinity were determined. The SOI toposheets $57 \mathrm{O} / 8,11$ and 12 was used for preparing the base map of study area. In advance, IDW spatial interpolation technique was used to understand the groundwater chemistry. Finally the various water quality spatial contour maps were used in GIS for integration analysis to prepare the water quality map.

\section{RESULTS AND DISCUSSION}

The spatial water sampling location data and the attributes of the water sampling testing database are incorporated for generation of various spatial contour maps of major water quality. The minimum, maximum, and average values of groundwater parameters are represented in Table-1. With the chemical 
parameters viz., $\mathrm{pH}, \mathrm{EC}, \mathrm{TDS}$, cations and anions and their various thematic maps have been prepared using Arc GIS 9.3.

Table-1: Hydro-geochemical data of study area

\begin{tabular}{|c|c|c|c|}
\hline Parameters & Minimum & Maximum & Average \\
\hline $\mathrm{PH}$ & 6.45 & 8.41 & 7.54 \\
\hline $\mathrm{EC}(\mu \mathrm{s} / \mathrm{cm})$ & 445.00 & 3260.00 & 1506.08 \\
\hline TDS (ppm) & 102.00 & 2330.00 & 1044.40 \\
\hline $\mathrm{HCO}_{3}(\mathrm{mg} / \mathrm{l})$ & 134.60 & 395.20 & 251.55 \\
\hline $\mathrm{Ca}(\mathrm{mg} / \mathrm{l})$ & 90.80 & 321.50 & 162.43 \\
\hline $\mathrm{Mg}(\mathrm{mg} / \mathrm{l})$ & 22.40 & 88.40 & 57.17 \\
\hline $\mathrm{Cl}(\mathrm{mg} / \mathrm{l})$ & 132.80 & 325.20 & 236.92 \\
\hline $\mathrm{Na}(\mathrm{mg} / \mathrm{l})$ & 136.00 & 303.00 & 210.63 \\
\hline $\mathrm{K}(\mathrm{mg} / \mathrm{l})$ & 4.90 & 9.50 & 7.64 \\
\hline $\mathrm{SO}_{4}(\mathrm{mg} / \mathrm{l})$ & 26.70 & 88.20 & 58.81 \\
\hline $\mathrm{PO}_{4}(\mathrm{mg} / \mathrm{l})$ & 0.44 & 0.82 & 0.64 \\
\hline $\mathrm{NO}_{3}(\mathrm{mg} / \mathrm{l})$ & 18.90 & 41.50 & 28.52 \\
\hline $\mathrm{F}(\mathrm{mg} / \mathrm{l})$ & 0.53 & 0.99 & 0.79 \\
\hline $\mathrm{H}_{2} \mathrm{SiO}_{4}(\mathrm{mg} / \mathrm{l})$ & 22.00 & 38.00 & 28.08 \\
\hline
\end{tabular}

pH

$\mathrm{pH}$ is a significant parameter in evaluating acidity or alkalinity of water. $\mathrm{Th}$ e computation of $\mathrm{pH}$ is to determine the intensity or alkalinity and measures the concentration of hydrogen ions. The study area $\mathrm{pH}$ value ranges from 6.45 to 8.41 with an intermediate value of 7.54 . As per standards the study area $\mathrm{pH}$ value classified into three categories of Excellent (7.0 to 8.0), Good (6.5 to 7.0) and Moderate (8.0 to 8.5) as shown in Fig.-2. The higher proportion of $\mathrm{pH}$ is by the influence of high biological activity and can also by the uptake of $\mathrm{CO}_{2}$ by photosynthesizing organisms ${ }^{2}$.

\section{Electrical Conductivity}

The study area electrical conductivity value ranges $445(\mu \mathrm{s} / \mathrm{cm})$ to $3260(\mu \mathrm{s} / \mathrm{cm})$ with an average of $1506.08 \mu \mathrm{s} / \mathrm{cm}$. The EC value ranges classified into four categories of Excellent (300 to $800 \mu \mathrm{s} / \mathrm{cm}$ ), Good (800 to $1000 \mu \mathrm{s} / \mathrm{cm}$ ), Moderate $(1000$ to $1500 \mu \mathrm{s} / \mathrm{cm}$ ) and Poor (above $1500 \mu \mathrm{s} / \mathrm{cm}$ ) were prepared and presented in Fig.-3. The most of the study area falls under the Moderate and Poor EC value due to the reason of salinity, industrial waste, and anthropogenic activity.

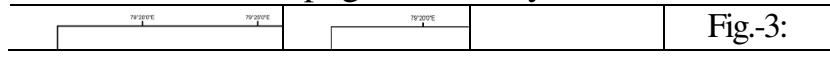

\section{Total dissolved solids}

The analysis of TDS for study area shows the minimum $102 \mathrm{mg} / \mathrm{l}$ and the maximum of $2330 \mathrm{mg} / \mathrm{l}$. Further, the understanding of the spatial distribution of interpolation was carried out. The value of TDS divided into four major categories namely Excellent ( $<500 \mathrm{mg} / \mathrm{l}$ ), Good (500 to $1000 \mathrm{mg} / \mathrm{l}$ ), Fair (1000 to 1500 $\mathrm{mg} / \mathrm{l})$ and Poor (>1500 mg/l) as shown in Fig.-4. The spatial distribution map shows the major part of the study area is good, which occupy the western and south-central part of the basin. The small four patches of the excellent category are also observed in the area. Then the southern part of basin shows the fair category of TDS. The poor category is observed eastern part of the basin.

\section{$\mathrm{HCO}_{3}$}

Bicarbonate represents the important sum of alkalinity, and it is a measure of its capacity of neutralization in water. $\mathrm{HCO}_{3}$ is mainly formed due to the presence of atmospheric $\mathrm{CO}_{2}$ and $\mathrm{CO}_{2}$ released from organic decomposition. The study area, bicarbonate value ranges from 134.60 to $395.20 \mathrm{mg} / \mathrm{l}$ with an average value of $251.55 \mathrm{mg} / \mathrm{l}$. The study area $\mathrm{HCO}_{3}$ spatial contour map classified into three categories of Excellent (200 to $300 \mathrm{mg} / \mathrm{l})$, Good (300 to $400 \mathrm{mg} / \mathrm{l})$ and Poor $(<200 \mathrm{mg} / \mathrm{l})$ as shown in Fig.-5. 


\section{Calcium}

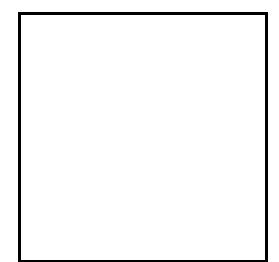

Fig.-4: TDS

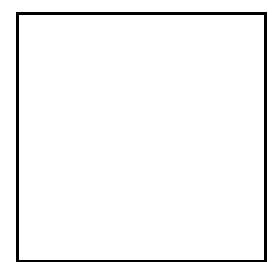

Fig.-5: $\mathrm{HCO}_{3}$

Calcium is an important constituent in natural water. The concentration of calcium ranges from 90.8 to $321.5 \mathrm{mg} / \mathrm{l}$ observed in the study area. The spatial contour map of study area Ca classified into three categories of Good (<100 mg/l), Moderate (100 to $200 \mathrm{mg} / \mathrm{l})$ and Poor (>200 mg/l) as shown in Fig.-6. The moderate amount of calcium was observed throughout the study area due to the influence of industrial and untreated sewage water released into the river / Pond. Hence when compared to the global average, it is suitable for aquatic systems ${ }^{8}$.

\section{Magnesium}

The study area groundwater magnesium ranges from 22.4 to $88.4 \mathrm{mg} / \mathrm{l}$ and average of $57.17 \mathrm{mg} / \mathrm{l}$. From this range values, the spatial contour map of magnesium has been prepared and shown in Fig.-7. The spatial contour map of study area Mg classified into two categories of Good $(<50 \mathrm{mg} / \mathrm{l})$ and Moderate (50 to $100 \mathrm{mg} / \mathrm{l})$. The concentrations of magnesium fall permissible limit within the study area.

\section{Chloride}

The study area, Chloride value varies between 132.8 to $325.2 \mathrm{mg} / \mathrm{l}$ with an average of $236.9 \mathrm{mg} / \mathrm{l}$, from this range values, the spatial contour map of chloride has been prepared and shown in Fig.-8. The spatial contour map of study area $\mathrm{Cl}$ classified into three categories Excellent ( $<200 \mathrm{mg} / \mathrm{l})$, Good (200 to 250 $\mathrm{mg} / \mathrm{l}$ ) and Moderate (250 to $1000 \mathrm{mg} / \mathrm{l})$.

\section{Sodium}

Sodium is the abundant and most important alkali mineral which is highly portable and soluble in groundwater. Groundwater with sodium value below $175 \mathrm{mg} / \mathrm{l}$ is portable ${ }^{11}$. The study area, sodium value range varies from 136 to $303 \mathrm{mg} / \mathrm{l}$ with an average of $210.63 \mathrm{mg} / \mathrm{l}$. The spatial contour map of study area $\mathrm{Na}$ classified into two categories of Good $(<250 \mathrm{mg} / \mathrm{l})$ and Poor $(>250 \mathrm{mg} / \mathrm{l})$ as shown in Fig.-9. It shows that most of the study area falls within the allowable limit. This clearly defined that $\mathrm{Na}$ is influenced less by physical weathering ${ }^{10}$.

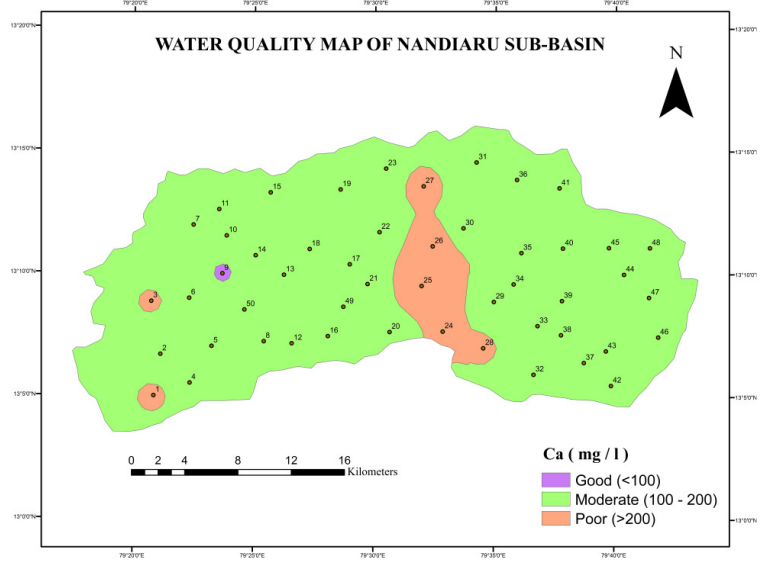

Fig.-6: $\mathrm{Ca}$

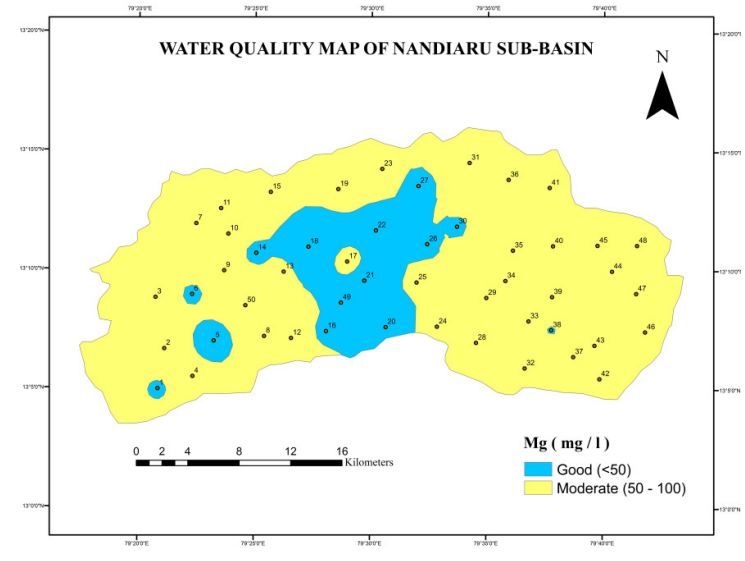

Fig.-7: Mg 

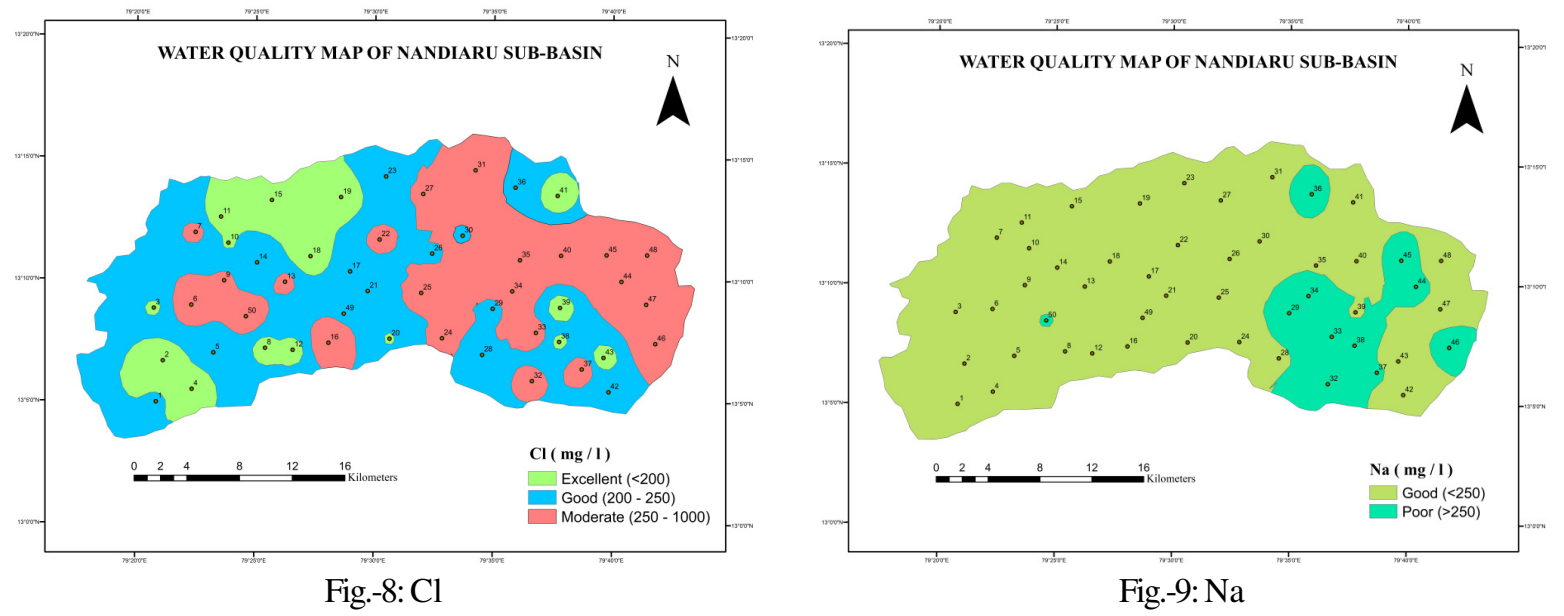

Fig.-9: $\mathrm{Na}$

\section{Potassium}

Potassium values of study area groundwater range from 4.9 to $9.5 \mathrm{mg} / \mathrm{l}$ with an average of $7.64 \mathrm{mg} / \mathrm{l}$. The $\mathrm{K}$ value is within the standard limit in the entire study area was shown in Fig.-10. The BIS standard value of Potassium (K) for drinking water is $10 \mathrm{mg} / \mathrm{l}$. The quantity of potassium is fairly stronger in the study area. The increase in the level of potassium is by the effluent discharge from industries and fertilizers used for agriculture field.

\section{Sulphate}

Natural water contains sulphate ions and the majority of these ions are also soluble in water. Many sulphate ions are turned out by oxidation process of their ores, and moreover present in industrial wastes. Sulphate is dissolved most important components of the rain. The high concentration of $\mathrm{So}_{4}$ in drinking water caused the dehydration and diarrhea. Kids are habitually more sensitive to sulphate than adults. The method of measurement of sulphate quantity is by UV Spectrometer. As per BIS 10500:2012 ${ }^{1}$ the Sulphate desirable and permissible limit is $200 \mathrm{mg} / \mathrm{l}$ and $400 \mathrm{mg} / \mathrm{l}$ respectively. The sulphate range varies in the study area between 26.7 to $88.2 \mathrm{mg} / \mathrm{l}$ with an average of $58.81 \mathrm{mg} / \mathrm{l}$. The Sulphate concentrations in all samples are in the desirable limit. The spatial contour map Fig.-11 shows the only one range because the study area has $\mathrm{SO}_{4}$ in the desirable limit.

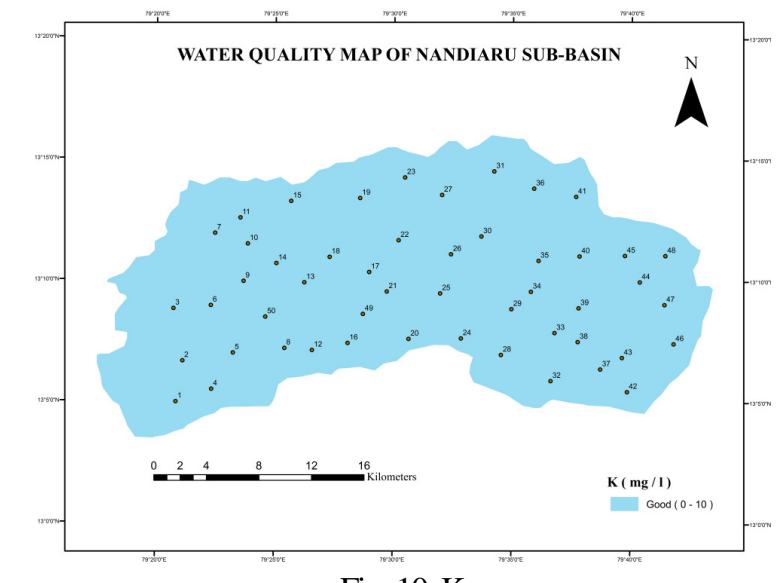

Fig.-10: K

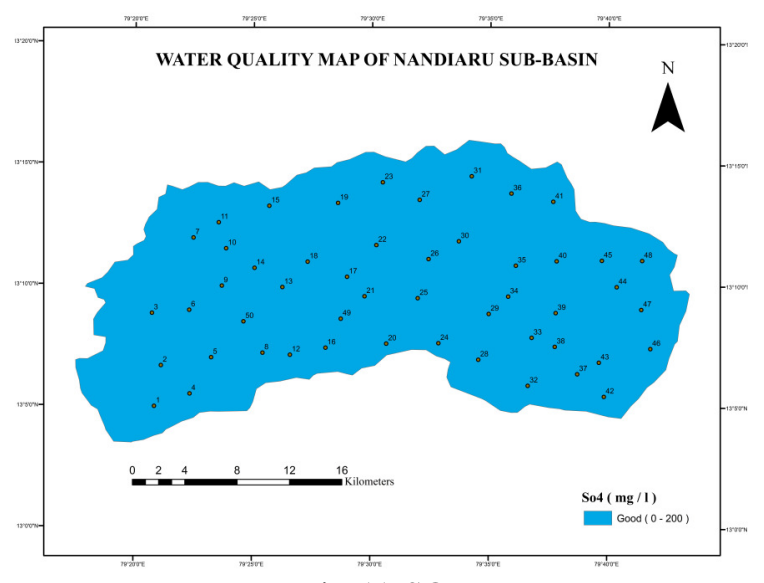

Fig.-11: $\mathrm{SO}_{4}$

\section{Phosphate}

Phosphates are chemical compounds contains mainly Phosphorous. The $\mathrm{Po}_{4}$ increases due to the activities of domestic sewage, agricultural runoff water from crop lands, sewage from animal feedlots, vegetable and fruit processing, chemical and fertilizer. Generally, the groundwater contains only a lowest phosphorous level due to the reason of soil have the ability to hold the phosphate. The concentration of 
$\mathrm{Po}_{4}$ in the study area ranges from 0.44 to $0.82 \mathrm{mg} / \mathrm{l}$, with an average of $0.64 \mathrm{mg} / \mathrm{l}$. The spatial contour map Fig.-12 shows a low concentration of $\mathrm{Po}_{4}$ in groundwater from NandiAru sub-basin has observed and also it is limited to BIS standard.

\section{Nitrate}

Nitrate is one of the most general ground water contaminants in rural areas. It is synchronized in drinking water primarily because surplus level can cause "methemoglobineamia" or "Blue baby" disease. The study area Nitrate concentration is varied from 18.9 to $41.5 \mathrm{mg} / \mathrm{l}$. The spatial contour map of study area Nitrate value is categorized as Excellent ( $<20 \mathrm{mg} / \mathrm{l})$, Good $(20$ to $30 \mathrm{mg} / \mathrm{l})$ and Moderate (30 to $45 \mathrm{mg} / \mathrm{l})$ classes as shown in Fig.-13. The permissible limit of Nitrate concentration is 45mg/l according to BIS 10500:2012.

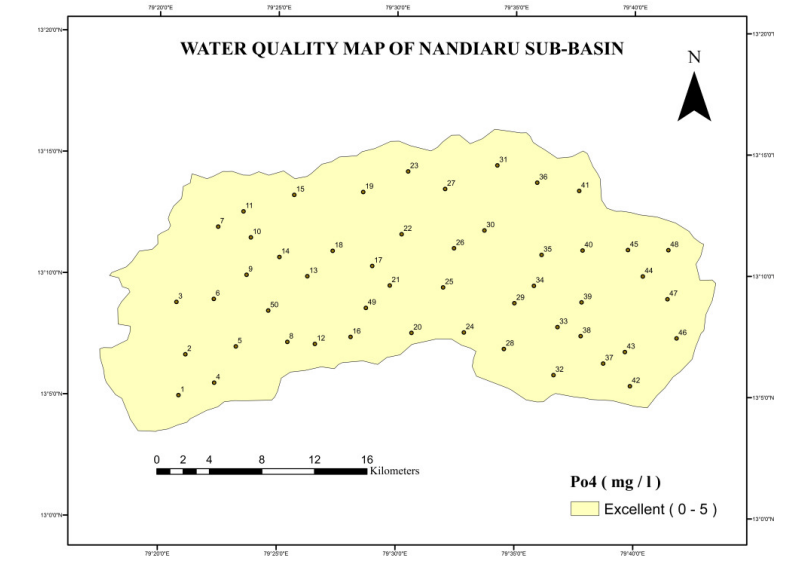

Fig.-12: $\mathrm{PO}_{4}$

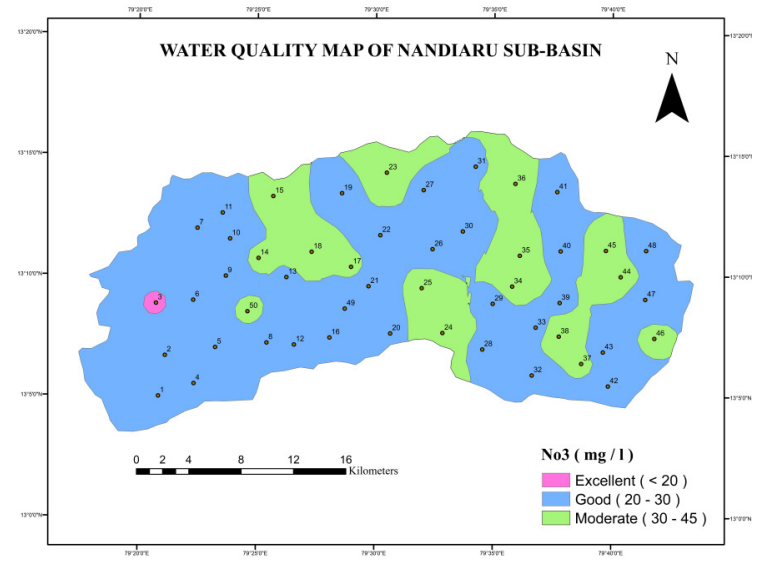

Fig.-13: $\mathrm{NO}_{3}$

\section{Fluoride}

Fluoride value in the study area groundwater ranges from 0.53 to $0.99 \mathrm{mg} / \mathrm{l}$ with an average of $0.79 \mathrm{mg} / \mathrm{l}$ was observed. As per BIS standards, the desirable and permissible limit of drinking water for Fluoride is $1.0 \mathrm{mg} / \mathrm{l}$ and $1.5 \mathrm{mg} / \mathrm{l}$ respectively. The spatial contour map of Fluoride has been prepared and presented as shown in Fig.-14.

\section{$\mathrm{H}_{2} \mathrm{SiO}_{4}$}

The study area Silica concentration of drinking water range varies from 22 to $38 \mathrm{mg} / \mathrm{l}$ with an average of 28.08 $\mathrm{mg} / \mathrm{l}$. The spatial contour map of study area $\mathrm{H}_{2} \mathrm{SiO}_{4}$ value is categorized as Good $(<20 \mathrm{mg} / \mathrm{l})$ and Moderate $(25$ to $50 \mathrm{mg} / \mathrm{l}$ ) classes as shown in Fig.-15. Generally, silica is found the range of $25 \mathrm{mg} / \mathrm{l}$ for drinking water. Higher concentrations normally occur in highly alkaline water.

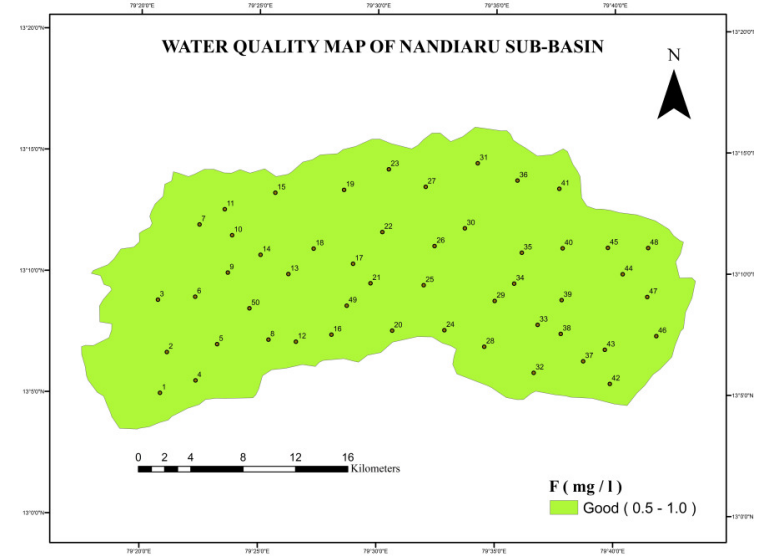

Fig.-14: F

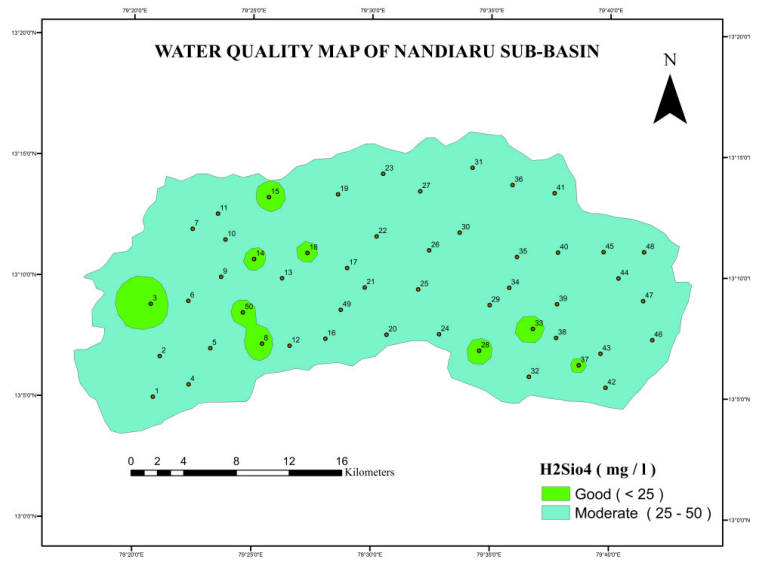

Fig.-15: $\mathrm{H}_{2} \mathrm{SiO}_{4}$ 


\section{Groundwater Quality Map}

The thematic map of groundwater quality parameters, such as pH, TDS, Electrical Conductivity(EC), Calcium $(\mathrm{Ca}), \quad$ Magnesium $(\mathrm{Mg}), \quad \operatorname{Sodium}(\mathrm{Na}), \quad$ Chloride $(\mathrm{Cl}), \quad$ Potassium $(\mathrm{K}), \quad$ Sulphates(So $)$, Phosphate $\left(\mathrm{PO}_{4}\right)$, Nitrate $\left(\mathrm{NO}_{3}\right)$, Fluoride $(\mathrm{F})$ and $\mathrm{H}_{2} \mathrm{SIO}_{4}$ were used for overlay integration analysis to prepare the groundwater quality map of NandiAru sub-basin using Geo spatial technology shown in Fig.16. Final groundwater quality map of GIS integration shows Excellent to Poor quality groundwater zone classifications in the study area. The percentage of area influenced by the groundwater quality zones are Excellent (35.28\%), good (27.64\%), Moderate (12.41\%) and Poor (24.67\%) depending on the weights were assigned to spatial contour layers. Further the groundwater quality map shows that, the western part of the study area Gopalapuram, Palasamudram, Kollureddykandigai and Mottur has excellent groundwater quality, while the central portion of study area covered stretch of Good groundwater quality zones. The moderate to the poor quality of groundwater zones are widely covered in the eastern part of the study area and a small portion of RK Pet, Mahankalikapuram, Nochili and Veeranathur.

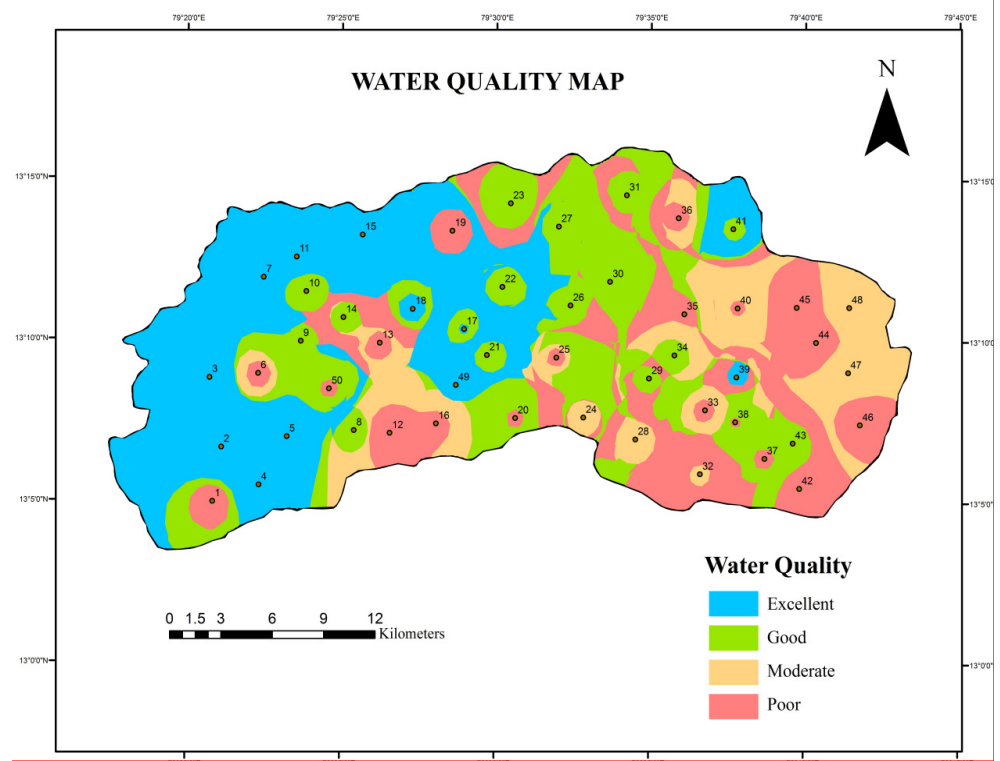

Fig.-16: Water Quality Map

CONCLUSION

The spatial representation of groundwater quality analysis indicates that the study area needs a few measures of treatment before utilization of groundwater. The study facilitates to understand the existing groundwater quality conditions and to develop appropriate management practices to protect the groundwater sources. The most significant pollutants observed in the present study area are EC, TDS, Alkalinity, Calcium, Magnesium and Sodium needs to be monitored regularly as the map shows where the value is above the desirable limit. It can be concluded that the growing population and urbanization, the groundwater quality must be monitored on regular basis. The geospatial technology has been useful for groundwater quality mapping as well as the study will helpful for future planning of groundwater development programme.

\section{ACKNOWLEDGMENT}

The authors would like to thank SRM Institute of Science and Technology and GRT Institute of Engineering \& Technology for giving full support and constant encouragements for doing this research work.

\section{REFERENCES}

1. BIS, Specifications for drinking water, New Delhi: IS: 10500.2012.

2. C. L. Govindasamy, Kannan and Jayapaul Azariah, J. Environ. Biol., 21(1), 1(2000).

3. F. M Hassan, Maysoon M. Saleh and Jasim M. Salman, E-Journal of Chemistry, 7(3), 685(2010). 
RASĀYAN J. Chem.

Vol. 11 | No. 2 |735 - 742 | April - June | 2018

DOI: $10.1155 / 2010 / 906837$

4. Sanjay Kumar Goyal, B. S. Choudhary, Environ Earth Sci. (2010), DOI: 10.1007/s12665-010-0472$\mathrm{Z}$

5. M. Milovanovic, Desalination, 213, 159-173, (2007).

6. Rajesh Arora, Harish Chandra Joshi, I.P.Pandey and V.K.Tewari, Rasayan J. Chem. ,10(4),1167(2017), DOI: 10.7324/RJC.2017.1041753

7. Rajesh P. Ganorkar, Harshali A. Hole and Dinesh A. Pund, Rasayan J. Chem., 10(2),429(2017). DOI: 10.7324/RJC.2017.1021665

8. M. M. Sarin and S. Krishnaswamy, Nature, 312(5994), 538(1984), DOI: 10.1038/312538a0

9. S. Venkateswaran, S. Karuppannan, and K. Shankar, International Journal of Recent Scientific Research, 3(10), 782 (2012).

10. V Subramanian, Geol. Water Sci., 9, 93(1987), DOI: 10.1007/BF02449940

11. WHO Geneva, 3rd edition in corpora ting 1st and 2nd add, Vol. 1, Recommendations, (2008).

[RJC-1837/2017] 